\title{
Erratum to: Effects of aerobic exercise on the blood pressure, oxidative stress and eNOS gene polymorphism in pre-hypertensive older people
}

\author{
Anderson Saranz Zago $\cdot$ Joon-Young Park $\cdot$ \\ Nicola Fenty-Stewart · Eduardo Kokubun • \\ Michael D. Brown
}

Published online: 3 September 2010

(C) Springer-Verlag 2010

\section{Erratum to: Eur J Appl Physiol}

\section{DOI 10.1007/s00421-010-1568-6}

Two mistakes occurred in the original publication:

The list of authors was incorrect. It should read:

Anderson Saranz Zago, Joon-Young Park, Nicola FentyStewart, Eduardo Kokubun, Michael D. Brown

The attribution of funding in the Acknowledgments was incorrect:

The Fundação de Amparo a Pesquisa do Estado de São Paulo, FAPESP (04/07779-4) did not support this project. It should read: Department of Kinesiology / University of Maryland.

The online version of the original article can be found under doi:10.1007/s00421-010-1568-6.

\footnotetext{
A. S. Zago (ه)

School of Physical Education and Sport of Ribeirão Preto,

University of São Paulo, Av. Bandeirantes, 3900-Monte Alegre,

Ribeirão Preto, São Paulo 14040-900, Brazil

e-mail: aszago@hotmail.com; aszago@usp.br

J.-Y. Park · N. Fenty-Stewart · M. D. Brown

Department of Kinesiology, Temple University,

Philadelphia, USA

E. Kokubun

Department of Physical Education, UNESP, Rio Claro, Brazil
} 